\title{
ANALISIS PELAKSANAAN KURIKULUM 2013 DITINJAU DARI STANDAR PENILAIAN DALAM PEMBELAJARAN MATEMATIKA KELAS VIII DI SMP NEGERI 18 PADANG
}

\author{
Sherly Wahyuni, Sefna Rismen, Alfi Yunita \\ Program Studi Pendidikan Matematika STKIP PGRI Sumatera Barat \\ Sherlywahyuni3797@gmail.com
}

\begin{abstract}
The purpose of this study is to describe and analyze the assessment mechanisms and procedures in accordance with 2013 curriculum rules. This research is a qualitative descriptive study. Subjects in this study were mathematics teachers in class VIII SMP Negeri 18 Padang, amounting to two teachers. The instruments used in this study include documentation, observation, and interviews. Data analysis techniques include data reduction, presentation, data verification, and data triangulation. The results of this study indicate (a) in terms of the assessment mechanism of eighth grade mathematics teachers at SMPN 18 Padang not yet perfect in implementing the assessment mechanism stipulated in Permendikbud No. 23 of 2016 The imperfect indicators are 1) carry out attitude assessments with various assess,emt techniques, 2) carry out skills assessments with varios asessment techiques. (b) in terms of the assessment procedure for eighth grade mathematics teachers at SMPN 18 Padang, it is also perfect to carry out the assessment procedures stipulated in Ministry of Education and Culture Regulation No. 23 of 2016. As for the imperfect indicators, namely 1) determining the purpose of the assessment, 2) make analysis of instrument quality, 3) processing, analyzing, and interpreting the assessment, 4) reprting the reults of the assessment, 5) utilizing the results of the asessment report.
\end{abstract}

\section{Keywords : Curriculum 2013, Assessment Standards}

\section{PENDAHULUAN}

Pendidikan adalah usaha sadar dan terencana untuk mewujudkan suasana belajar dan proses pembelajaran agar peserta didik secara aktif mengembangkan potensi dirinya untuk kekuatan spiritual keagamaan, pengembalian diri, kepribadian, kecerdasan akhlak mulia dan keterampilan yang diperlukan
Masyarakat bangsa dan negara Helmawati (2019). Menciptakan hal tersebut diperlukan pola dan sistem pendidikan yang baik salah satunya terwujud kurikulum. Kurikulum adalah seperangkat rencana dan pengaturan mengenai isi dan bahan pelajaran serta cara yang digunakan sebagai pedoman penyelenggara kegiatan belajar mengajar Daktir dalam Jaya Paldi 
(2019). Poerwati loeloek Endah dan Sofan Amri (2013) berpendapat bahwa kurikulum adalah sebuah panduan yang berisi tahapan dan alat yang digunakan oleh guru pada dunia pendidikan. UU Nomor 20 (2003) pasal 36 yang mengemukakan kurikulum dikembangkan dilihat dari standar nasional pendidikan. Lingkup standar nasional pendidikan mencakup standar pembiayaan, standar kompetensi lulusan, standar sarana prasarana, standar pengelolaan, standar isi, standar kependidikan, standar proses, dan standar penilaian Permendikbud (2013). Berdasarkan penjelasan diatas salah satu diantaranya yaitu Standar Penilaian. Permendikbud (2016) mengungkapkan bahwa standar penilaian adalah kriteria mengenai tujuan, instrumen, manfaat, prosedur, prinsip, mekanisme, dan lingkup penilaian hasil belajar peserta didik yang digunakan sebagai dasar dalam penilaian hasil belajar peserta didik pada pendidikan dasar dan pendidikan menengah.

Tujuh dari standar penilaian tersebut maka peneliti mengambil mekanisme penilaian dan prosedur penilaian. Mekanisme penilaian merupakan rancangan yang digunakan guru untuk melakukan pembelajaran. Jadi, hal pertama yang harus dilakukan guru yaitu melakukan proses penilaian dengan merancang stategi penilaian saat penyusunan RPP yang berpedoman pada silabus. Perancangan pada pembuatan RPP yaitu aspek sikap, keterampilan serta pengetahuan yang menggunakan teknik-teknik yang telah di tetapkan dalam kurikulum 2013. Pada penilaian sikap teknik yang digunakan yaitu jurnal serta bentuk lainnya yang relevan. Penilaian pengetahuan teknik yang digunakan berbentuk tes tertulis, penugasan, dan teknik lainnya yang relevan. Penilaian keterampilan teknik yang digunakan yaitu portofolio, proyek, dan produk. Menggunakan aspek penilaian sikap, keterampilan dan pengetahuan tersebut harus sesuai dengan kompetensi dasar dan indikator pembelajaran. Prosedur penilaian mengacu pada tuntutan kurikulum 2013, dimana dalam prosedur penilaian menggunakan berbagai penilaian. Penilaian ini telah memiliki prosedur masing-masing dalam Permendikbud (2016). Prosedur ini lah yang harus guru laksanakan dalam proses pembelajaran. 
Aiman (2016) mengungkapkan bahwa pelaksanaan penilaian autentik kurikulum 2013 di MIN belum sepenuhnya terlaksana sesuai dengan prosedur penilaian autentik. Faktor penghambat dalam pelaksanaan penilaian autentik yaitu pemahaman guru tentang proses dan instrumen penilaian autentik yang masih minim. Waktu melakukan observasi di SMPN 18 Padang kepada guru matematika kelas VIII menunjukkan bahwa permasalahan yang terdapat saat mengajar yaitu belum terlaksananya penilaian keterampilan. Belum terlaksananya penilaian keterampilan disebabkan karena keterbatasan waktu. Kurangnya waktu yang diberikan membuat guru susah untuk melaksanakan semua aspek penilaian, karena selain memberi materi, guru juga mengamati setiap perilaku peserta didik. Dengan demikian membuat waktu lebih banyak di gunakan saat menerangkan materi serta melihat pengembangan peserta didik demi tercapainya tujuan proses belajar mengajar.

\section{METODE PENELITIAN}

Peneliti menggunakan bentuk deskriptif kualitatif. Waktu meneliti dilaksanakan pada bulan Januari tahun 2020 pada semester genap tahun 2019/2020. Penelitian ini dilaksanakan di SMPN 18 Padang kelas VIII dengan tiga kali pertemuan pada masingmasing guru. Subjek penelitian yaitu guru matematika kelas VIII SMPN 18 Padang yang berjumlah dua orang guru. Dokumentasi, observasi, dan wawancara bagian dari instrumen pengumpulan data. Triangulasi merupakan bagian dari keabsahan data serta menganalisisya secara deskriptif kalitatif. Hasil observasi, dokumentasi, dan wawancara di analisis menggunakan tahapan dari Miles dan Huberman dalam (Sugiyono, 2013). Bentuk data yang digunakan berupa narasi atau teks deskripsi kualitatif.

\section{HASIL DAN PEMBAHASAN}

1. Mekanisme Penilaian

a. Membuat Strategi Penilaian Berdasarkan Silabus.

Berdasarkan hasil dokumentasi dapat dilihat bahwa guru sudah merancang strategi penilaian yang dibuat saat pembuatan RPP. Bentuk 
rancangan strategi penilaian yang digunakan saat pembuatan perangkat berdasarkan silabus yaitu keterampilan, sikap dan pengetahuan. Bentuk penilaian sikap yang digunakan kedua guru yaitu berdo'a, mengucapkan salam, bersyukur, tanggung jawab, disiplin, dan santun. Bentuk penilaian pengetahuan yang dibuat oleh guru A berupa tes tertulis dalam bentuk kuis yang disertai dengan pedoman penskoran dalam bentuk uraian. Bentuk penilaian keterampilan yang digunakan oleh guru A yaitu penilaian proyek yang disertai dengan pedoman penskoran. Bentuk rancangan penilaian yang dibuat oleh guru B pada pengetahuan dengan menggunakan berbagai teknik penilaian. Penilaian keterampilan menggunakan tes tertulis. Hasil wawancara yang dilakukan bahwa guru dalam merancang strategi penilaian berdasarkan kompetensi dasar dan indikator penilaian.

Pada silabus bentuk rancangan penilaian sikap yang digunakan berupa rasa tanggung jawab, disiplin, santun, menyimak, dan menjelaskan, pengetahuan yang digunakan berupa tes tertulis dan penugasan dalam hal ini guru dalam merancang strategi penilaian sikap yang berdasarkan silabus hanya mengambil beberapa indikator saja. Pengambilan beberapa indikator tersebut berdasarkan materi yang digunakan pada saat proses pembelajaran, pengambilan penilaian pengetahuan yang digunakan oleh guru berdasarkan silabus berupa penilaian tes tertulis, dan penugasan. Pada pengambilan penilaian keterampilan berdasarkan materi berupa penilaian proyek, praktek, dan tes tertulis berdasarkan pada materi yang digunakan. Menurut Santoso menyatakan bahwa indikator yang dibuat berupa bentuk, teknik, contoh, serta instrumen penilaian pada setiap aspek. Sedangkan pada Permendikbud (2016) perancangan strategi penilaian dilaksanakan waktu penyusunan perangkat di silabus.

b. Melaksanakan Penilaian Sikap Dengan Berbagai Teknik Penilaian.

Hasil dokumentasi mengungkapkan bahwa penilaian 
sikap yang dilaksanakan kedua guru pada meteri garis singgung lingkaran menggunakan lembaran penilaian observasi. Lembaran observasi yang digunakan oleh guru A berupa lembaran penilaian sikap spiritual dan sikap sosial. Data tersebut di perkuat dari hasil wawancara dari guru A yang menyatakan bahwa penilaian yang dilakukan oleh guru A berupa observasi, jurnal dan penilaian diri. Kenyataanya saat melakukan pengamatan guru A hanya menggunakan penilaian sikap berupa observasi, jurnal penilaian sikap spiritual dan sikap sosial, untuk penilaian diri yang dilakukan guru A dilaksanakan sekali dalam satu semester. Pada penilaian yang dilakukan oleh guru B berupa lembaran penilaian sikap sosial dan sikap spiritual. Penilaian tersebut belum digunakan oleh guru B karena guru B menggunakan lembaran absen dalam menilai sikap peserta didik, seharusnya guru B menggunakan lembaran penilaian sikap yang telah dirancang saat pembuatan RPP. Kemendikbud (2017) penilaian sikap pada kurikulum 2013 terbagi menjadi dua bagian yaitu sosial dan spiritual yang tertera di kompetensi inti I, dan kompetensi inti II. Pada kompetensi inti I bentuk sikap spiritual yang telah ditetapkan yaitu saling menghargai antar agama, untuk penilaian sosial yang tertera di kompetensi inti II berupa gotongroyong, kejujuran, percaya diri, dan sebagainya.

Jalaludin dalam Mardhiyana \& Jailani (2017) penilaian pada kompetensi inti 1 lebih mengarah pada religiusinitas. Religiusinitas adalah perilaku beragama, dengan kegiatan mendorongnya pada ketaatan terhadap keagamaan. kompetensi inti II lebih mengarah pada sikap sosial, yang di kembangkan diantaranya adalah keingintahuan, bertangung jawab, dan percaya diri. Kedua kompetensi yang telah dijabarkan tersebut menggunakan lembaran penilaian sikap dengan mengunakan teknik penilaian yang telah ditetapkan. Setiadi (2016) menyatakan bahwa teknik penilaian sikap menggunakan penilaian diri, observasi, teman sejawat, dan jurnal. Hal ini juga 
sesuai dengan Permendikbud (2016) menyatakan teknik penilaian sikap berupa observasi, jurnal, penilaian antar teman, percaya diri, dan bentuk lainnya yang relevan.

Bentuk penilaian antar teman dan percaya diri seharusnya juga digunakan oleh kedua guru pada kurikulum 2013. Dengan menggunakan penilaian percaya diri dan penilaian antar teman guru lebih mudah dalam menilai sikap spirilual dan sikap sosial peserta didik. Hal ini dapat disimpulkan bahwa kedua guru belum sempurna melaksanakan penilaian sikap berdasarkan ketetapan Permendikbud (2016)

c. Melaksanakan Penilaian Pengetahuan Dengan Berbagai Teknik Penilaian

Hasil dokumentasi yang dilaksanakan dapat dilihat bahwa dalam mengukur pemahaman peserta didik, guru memilih teknik aspek pengetahuan yaitu tes tertulis dalam bentuk kuis. Hasil wawancara yang dilakukan guru A memilih tes tertulis dan tes lisan. Guru A juga mengatakan bahwa penilaian tes tertulis berupa presentasi di depan kelas. Kenyataan yang dilihat pada observasi guru menggunakan kuis dan presentasi hasil diskusi di depan kelas. Guru B dalam menilai pengetahuan peserta didik menggunakan tugas. Saat melakukan wawancara dengan guru B, bahwasannya guru B menggunakan dua teknik penilaian yaitu tes tertulis berupa latihan pada buku LKS peserta didik dan tes lisan.

Teknik penilaian tes tertulis berupa, menjodohkan, salah-benar, dan objektif. Teknik lisan yang tertera pada pedoman penilaian kurikulum 2013 berupa tanya jawab. Teknik penugasan yang ada pada pedoman penilaian guru pada kurikulum 2013 dalam bentuk penugasan dilaksanakan secara individual maupun berkelompok Kemendikbud (2017).

d. Melaksanakan Penilaian Keterampilan Dengan Berbagai Teknik Penilaian

Hasil dokumentasi yang telah dilakukan bahwa guru A menggunakan bentuk penilaian proyek dalam penilaian keterampilan peserta didik. Saat melakukan wawancara dengan guru 
A, bahwa guru A menggunakan dua teknik penilaian keterampilan yaitu praktek dan proyek. Penilaian praktek dilakukan pada satu kompetensi dasar. Penilaian praktek menggambar sebuah lingkaran dengan menggunakan jangkar. Kenyataan yang di lakukan guru menggunakan penilaian praktek dengan materi garis singgung lingkaran, dan guru tidak menggunakan penilaian proyek. Pedoman penskoran yang dibuat guru pada penilaian keterampilan berupa pedoman penskoran proyek. Seharusnya guru A membuat teknik penilaian praktek dan pedoman penilaian praktek dalam penilaian keterampilan, agar apa yang dilakukan dengan yang dibuat sesuai.

Guru B dalam penilaian keterampilan menggunakan tes tertulis. Hasil wawancara dengan guru B, penilaian keterampilan peserta didik dalam bentuk memberikan soal-soal. Waktu observasi guru memberi sebuah permasalahan di depan kelas setelah itu guru memberi instruktur mengerjakan pada buku latihan.
Zulhelmi dalam Sa'adah \& Sigit (2018) menyatakan penilaian keterampilan berupa pekerjaan kelompok yang di pahami peserta didik dalam bentuk unjuk kerja. Penilaian unjuk kerja adalah bentuk menilai tingat menguasai keterampilan peserta didik lewat kerja nyata Arifin dalam Sa'adah \& Sigit, (2018). Hal ini dapat diketahui bahwa guru B belum melakukan penilaian keterampilan berdasarkan dengan Permendikbud No 23 Tahun 2016 yang menggunakan berbagai teknik penilaian berupa praktek, proyek, produk dan portofolio.

e. Pemberian Remedial Kepada Peserta Didik Yang Belum Mencapai KKM

Hasil dokumentasi, dan wawancara yang dilakukan bahwa guru A dan guru B dalam melaksanakan pembelajaran remedial berupa kelompok atau perorangan tergantung pada ketuntasan yang telah didapat oleh peserta didik. Pemberian remedial yang dilakukan oleh guru matematika kelas delapan dengan pemberian ulangan materi pembelajaran kepada peserta didik 
yang nantinya diakhiri dengan pemberian soal-soal. Menurut Di, Ii, \& Sedayu (2016) remedial dilaksanakan setelah jam pembelajaran reguler yang di ikuti dengan peserta didik yang nilai evaluasi matematikanya yang belum mencapai kriteria ketuntasan dengan cara pemberian tugas Permendikbud (2016) menyatakan bahwa peserta didik yang nilainya masih dibawah rata-rata maka peserta didik mengikuti proses belajar remedial. Dengan demikian dapat disimpulkan bahwa guru sudah mempersiapkan remedial yang berpedoman pada Permendikbud No 23 tahun 2016.

f. Penilaian Disampaikan Dalam Bentuk Deskripsi Atau Angka

Hasil dokumentasi yang dilakukan kepada guru A dan guru B belum melakukan pengolahan penilaian secara keseluruhan, karena materi yang di ajarkan oleh guru baru satu kompetensi dasar. Pada pedoman penilaian pengolahan nilai dapat dilakukan apabila semua materi sudah di ajarkan, jadi guru matematika kelas delapan melaksanakan hasil penilaian pada akhir semester yang kemudian hasil dari pengolahan yang di buat oleh guru di deskripsikan dan di sampaikan dalam bentuk angka.

Hasil penilaian dilakukan oleh guru pada akhir semester. Hasil penilaian yang dibuat oleh guru berdasarkan kompetensi dasar yang ada pada materi pembelajaran. Nilai yang di ambil dari kompetensi dasar merupakan nilai tertinggi. Setelah semua nilai tersebut terkumpul guru mengambil nilai rata-rata. Penulisan penilaian dibuat dalam bentuk angka atau deskripsi.

2. Prosedur Penilaian

a. Membuat Tujuan Penilaian

Hasil dokumentasi yang dilakukan bahwa guru A dan guru B tidak membuat tujuan penilaian pada lembaran penilaian, seharusnya guru dalam membuat sebuah penilaian menetapkan tujuan penilaian, karena dengan menetapkan tujuan penilaian guru bisa melihat bahwa materi yang di ajarkan sudah terlaksana dengan baik atau belum sama sekali. Permendikbud (2016) menyatakan bahwa dalam membuat penilaian 
harus menentukan tujuan dalam penilaian.

b. Membuat Kisi-Kisi

Hasil dokumentasi yang telah dilakukan terlihat bahwa guru $\mathrm{A}$ ada membuat kisi-kisi penilaian pengetahuan berupa indikator dan soal. Pada penilaian keterampilan guru A tidak ada membuat kisi-kisi penilaian, dan guru B tidak ada membuat kisi-kisi pada semua aspek penilaian pada RPP. Kemendikbud (2017) menyatakan bahwa kisi-kisi pada aspek pengetahuan meliputi indikator, jumlah, bentuk soal, kompetensi dasar, materi pembelajaran, yang akan diberikan kepada peserta didik. Kisi-kisi penilaian keterampilan meliputi materi, indikator, serta teknik penilaian yang digunakan. Permendikbud (2016) guru membuat kisi-kisi penilaian. Pembuatan kisi-kisi merupakan pedoman yang digunakan untuk membuat pedoman penskoran pada setiap penilaian yang dilakukan. Oleh karena itu, penyusunan kisikisi penilaian harus dilaksanakan pada setiap penilaian, agar guru lebih mudah dalam melaksanakan penilaian pada proses pembelajaran.

c. Membuat Instrumen Penilaian Serta Pedoman Penskoran

Hasil dokumentasi pada guru A, dapat dilihat guru menggunakan instrumen penilaian pengetahuan berupa uraian, dengan menggunakan kriteria tugas, kriteria pengamatan dan rubrik yang tertera pada LKPD, instrumen penilaian, dan pedoman penskoran. Pada pedoman penskoran berupa uraian, guru $\mathrm{A}$ hanya memberikan skor 5 apabila peserta didik dapat menjawab soal dengan benar. Seharusnya guru A dalam membuat rubrik penilaian menggunakan skala penilaian supaya guru A nantinya lebih mudah menilai kemampun pengetahuan sesuai dengan jawaban yang di buat oleh pesera didik. Hasil dokumentasi dari guru B menjukkan guru B tidak menggunakan instrumen penilaian dan pedoman penskoran. Seharusnya guru dalam membuat penilaian harus membuat instrumen penilaian yang disertai dengan pedoman penkoran agar dapat lebih mudah dalam menilainya. 
Instrumen penilaian oleh dalam prosedur penilaian yang telah Kemendikbud (2017) terdiri dari di tetapkan oleh Permendikbud No penilaian pengetahuan berupa 23 Tahun 2016. menjodohkan, objektif, dan esay. Pada Permendikbud (2016) Penilaian keterampilan yaitu kriteria melakukan analisis kualitas tugas, kriteria lembar pengamatan instrumen merupakan bagian dari dan rubrik penilaian. Bentuk pedoman penskoran yang digunakan oleh guru dalam sebuah penilaian berupa rubrik beserta skala pada penilaian pengetahuan dan penilaian keterampilan. Peraturan Permendikbud (2016) menyatakan bahwa dalam penilaian adanya instrumen penilaian, karena intrumen penilaian merupakan pedoman bagi guru yang akan melakukan penilaian di dalam kelas.

d. Melakukan Analisis Kualitas Instrumen

penilaian. Melakukan analisis kualitas instrumen dilakukan sebelum dan sesudah instrumen digunakan, tujuan dari analisis kualitas instrumen agar instrumen yang dibuat mendapatkan kualitas yang tinggi.

e. Melakukan Penilaian

Melakukan penilaian sikap, yaitu pertama mengamati perilaku peserta didik saat belajar. Hasil observasi pada kedua guru saat mengamati perilaku peserta didik pada pembacaan do'a, asmaul

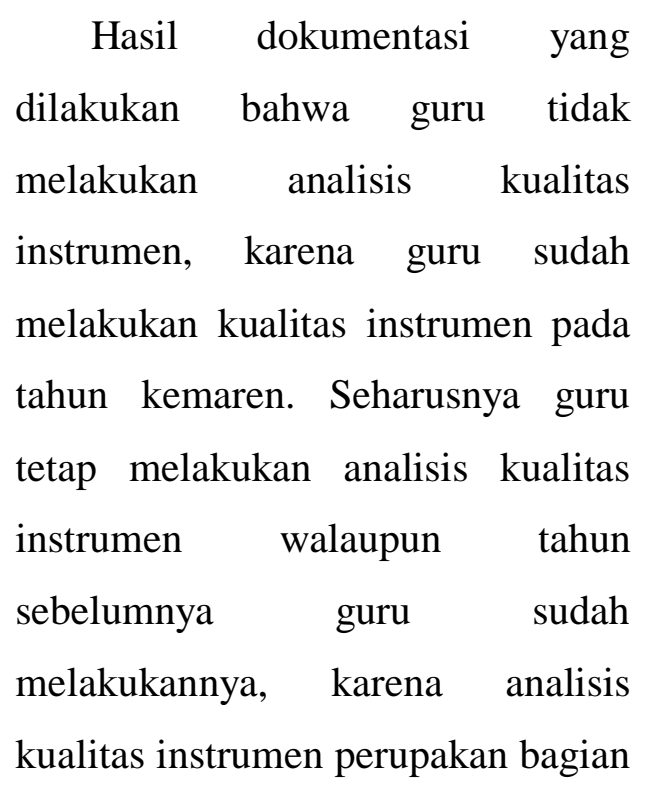
husnah dan pembelajaran kelompok. Prosedur penilaian sikap yang selanjutnya mencatat perilaku peserta didik. Hasil observasi yang dilakukan bahwa guru A mencatat sikap siswa pada lembaran observasi dan guru B mencatat sikap siswa pada lembaran absen, seharusnya guru B mencatat sikap siswa ke lembaran yang telah dibuat. 
Selanjutnya mendeskripsikan perilaku siswa, saat melakukan wawancara bahwa kedua guru mendeskripsikan perilaku peserta didik berupa angka. Ada beberapa prosedur sikap yang belum dilaksanakan oleh guru yaitu mencatat perilaku peserta didik pada lembaran observasi yang telah dirancang dalam RPP. Selanjutnya prosedur penilaian pengetahuan dan keterampilan pertama yaitu menyusun rancangan penilaian. Hasil wawancara yang telah dilakukan, guru A dalam penyusunan penilaian tertuang pada rencana pelaksanaan penilaian, dan guru B dalam menyusun perencanaan berdasarkan kompetesi dasar.

Prosedur penilaian pengetahuan dan keterampilan yaitu mengembangan penilaian. Hasil wawancara yang telah dilakukan guru A dalam mengembangkan penilaian sesuai dengan kompetensi dasar dan tujuan penilaian. Guru B dalam mengembangkan penilaian berdasarkan kompetensi dasar dan indikator penilaian. Selanjutnya prosedur penilaian pengetahuan dan keterampilan yaitu pelaksanaan penilaian. Hasil observasi yang dilakukan bahwa guru A dalam pelaksanaan penilaian pengetahuan menggunakan teknik penilaian tes tertulis berupa kuis. Hal tersebut sesuai pada perangkat guru A, guru B pada proses penilaian pengetahuan menggunakan penilaian tes tertulis pada proses pembelajaran. Pada penilaian kerampilan guru A menggunakan penilaian praktek dengan menggambar lingkaran menggunakan jangka, keyataanya tidak sesuai dengan hasil dokumen guru. Seharusnya guru menyesuaikan pelaksanaan penilaian pada apa yang telah dirancang pada RPP. Guru B menggunakan tes tertulis dengan pemberian soal saat pembelajaran. Permendikbud (2016) yang menyatakan bahwa teknik yang digunakan dalam penilaian keterampilan menggunakan berbagai penilaian berupa praktek, produk, projek dan portofolio. 
f. Menginterpretasikan, Menganalisis, dan Mengolah Penilaian

Hasil dokumentasi yang di lakukan ke dua guru belum ada mengolah, menganalisis, dan menginterpretasikan hasil penilaian. Pengolahan penilaian yang dilakukan oleh guru pada akhir semester. Pelaksanaan penilaian yang dilakukan selama sebulan sebelum penilaian diberikan kepada peserta didik.

g. Melaporkan Hasil Penilaian

Hasil dokumentasi yang telah dilakukan terlihat bahwa guru belum melaporkan hasil penilaian. Pada saat wawancara bahwa kedua guru dalam melaporkan hasil penilaian dilakukan pada akhir semester. Bentuk pelaporan hasil penilaian berupa angka dan deskripsi penilaian pada setiap aspek penilaian.

Permendikbud (2016) menyatakan bahwa dalam sebuah penilaian adanya pelaporan hasil penilaian. Pelaporan hasil penilaian digunakan untuk mengevaluasi sebuah penilaian yang dilakukan oleh guru. Jadi melaporkan hasil penilaian belum terlaksana, karena pelaporan dilakukan pada akhir semester.

h. Memanfaatkan Hasil Penilaian

Hasil dokumentasi yang dilakukan pada pemanfaatan hasil penilaian terlihat bahwa kedua guru belum melakukan pemanfaatan hasil penilaian, karena pemanfaatan hasil penilaian juga dilakukan pada akhir semester. Hasil wawancara yang dilakukan pada kedua guru bawa pemanfaatan hasil penilaian digunakan untuk penilaian rafor, untuk melihat apakah peserta didik layak untuk naik tingkat atau tidak, dan untuk mengevaluasi kemajuan dari peserta didik.

Pada Permendikbud (2016) menyatakan bahwa pemanfaatkan sebuah penilaian digunakan sebagai evaluasi. Jadi guru belum memanfaatkan hasil penilaian karena dalam pemanfaatkan hasil penilaian dilakukan pada akhir semester.

\section{KESIMPULAN}

1. Mekanisme Penilaian

Guru matematika kelas delapan di SMPN 18 Padang belum sempurna melaksanakan mekanisme 
penilaian yang sesuai pada Permendikbud (2016). Adapun indikator yang belum sempurna pada mekanisme penilaian yaitu 1) melaksanakan penilaian sikap dengan berbagai teknik penilaian 2) melaksanakan penilaian keterampilan dengan berbagai teknik penilaian.

2. Prosedur Penilaian

Guru matematika kelas delapan di SMPN 18 Padang belum sempurna melaksanakan prosedur penilaian yang sesuai dengan Permendikbud, 2016). Adapun indikator yang belum sempurna pada prosedur penilaian yaitu 1) menentukan tujuan penilaian, 2) membuat analisis kualitas instrumen, 3) menginterprentasikan, menganalisis, dan mengolah penilaian, 4) melaporkan hasil penilaian, 5) memanfaatkan laporan hasil penilaian.

\section{DAFTAR PUSTAKA}

Aiman, U. (2016). Evaluasi Pelaksanaan Penilaian Autentik Kurikulum 2013. Jurnal Pendidikan Madrasah, 1(P-ISSN: 2527-4287-E-ISSN: 2527-6794), 115-122.
Di, M., Ii, K., \& Sedayu, S. D. N. (2016). Pelaksanaan Pengajaran Remedial Pada Mata Pelajaran. Jurnal Pendidikan Guru Sekolah Dasar, 5, 362-369.

Helmawati. (2019). Pembelaaran dan Penilaian Berbasis HOTS. Bandung: PT Remaja Rosdakarya.

Jaya Paldi, J. (2019). Keterlaksanaan Standar Proses Pada Pembelajaran Matematika Menurut Kurikulum 2013 Pada Kelas XII SMA Negeri. Pythagoras: Jurnal Pendidikan Matematika, 14(1), 80-91. https://doi.org/10.21831/pg.v14i1. 21220

Kemendikbud. (2017). Panduan Penilaian oleh Pendidik dan Satuan Pendidikan Atas. (tim direktorat pembina SMP, Ed) (4th ed.). Jakarta: Kementrian Pendidikan dan Kebudayaan.

Mardhiyana, D., \& Jailani, J. (2017). Pengembangan Model Asesmen Pembelajaran Matematika SMA Berdasarkan Kurikulum 2013 Developing of Assessment Model of Mathematics Learning in Senior High School Based On Curriculum 2013. PYTHAGORAS: Jurnal Pendidikan Matematika, 12(2), 135-148.

Permendikbud. (2013). Perubahan Atas Peraturan Menteri Pendidikan Nasional Nomor 15 Tahun 2010 Tentang Standar Pelayanan Minimal Pendidikan Dasar di Kabupaten/Kota. 
Permendikbud. (2016). Nomor 23

Tahun 2016 Tentang Standar

Penilaian Pendidikan.

https://doi.org/10.1017/CBO9781

107415324.004

Poerwati loeloek Endah dan Sofan Amri. (2013). Panduan Memahami Kurikulum 2013. Jakarta: PT. Prestasi Pustakaraya.

Sa'adah, E. N. L., \& Sigit, D. (2018). Pengembangan Instrumen Penilaian Sikap dan Keterampilan Psikomotorik pada Materi Elektrokimia. Jurnal Pendidikan: Teori, Penelitian, Dan Pengembangan, 3(8), 1023-1026. https://doi.org/10.17977/JPTPP.V 3I8.11405

Santoso, R. H. (2015). Implementasi Pendekatan Saintifik Mapel Matematika Kelas VII Tahun Pelajaran 2013/2014 pada Kurikulum 2013 DIY. Pythagoras: Jurnal Pendidikan Matematika, 10(1), 80-94. https://doi.org/10.21831/pg.v10i1. 9112

Setiadi, H. (2016). Pelaksanaan Penilaian Pada Kurikulm 2013. Penelitian Dan Evaluasi Pendidikan, 2.

Sugiyono. (2013). Metode Penelitian Bisnis. Bandung: Alfabeta.

UU Nomor 20. (2003). Tentang Sistem Pendidikan Nasional, Zitteliana §. 